FEATURE

\title{
The Management and Support of Outreach in Academic Libraries
}

The promotion of services in academic libraries often falls under the purview of outreach. This paper explores a number of questions regarding library outreach, specifically how libraries manage and support the marketing and public relations aspect of their services, resources, and facilities. An exploratory survey of more than 100 academic libraries reveals that the management of outreach often occurs on an informal and ad hoc basis, with only a minority maintaining a dedicated budget or articulated mission statement. Overwhelmingly, campus and library events prove the most popular methods of outreach, although blogs and other Web 2.0 tools trail closely behind. Additional survey questions address the use of dedicated positions and committees, and future efforts planned for outreach. This paper should provide a gauge for libraries in measuring their outreach efforts, while also highlighting topics for further study.

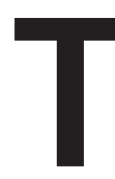

he vast amount of literature published on outreach suggests that libraries, in an effort to remain viable in the face of competing information outlets, recognize the need to reach out to their users. In the words of Hallmark, Schwartz, and Roy,

Gone are the days when libraries can simply open their doors and expect to be perceived as the number one option for information services. With fierce competition for funding and more people assuming everything offered by a library can be found online, libraries are feeling the pressure to blow their own horn. ${ }^{1}$

Such a relevant topic deserves examination, but no standard definition of outreach exists within the academic library community. Assumptions can be made about a definition, however, by exploring the types of activities that academic libraries label with the outreach moniker. A review of the literature reveals two distinct, yet interconnected types of outreach activities: (1) services offered by libraries and (2) promotion of these services. This paper focuses on the second category of outreach, and examines how academic libraries manage and support the promotion of their libraries through marketing and public relations. The authors conducted an exploratory survey of library outreach at academic libraries across the country, inquiring about dedicated outreach positions, outreach committees, mission statements, staff time and financial resources allocated to outreach, and libraries' future plans for outreach. Over 100 libraries of various sizes and types, including community colleges and both

\section{Toni M. Carter and \\ Priscilla Seaman}

Toni M. Carter is Instruction and Reference Librarian, Auburn University. Priscilla Seaman is Reference and Instruction Librarian, The University of Tennessee at Chattanooga. Submitted for review March 31, 2011; revised and accepted for publication July 14, 2011.

Reference \& User Services Quarterly, vol. 51, no. 2, pp. 73-81 (c) 2011 American Library Association. All rights reserved.

Permission granted to reproduce for nonprofit, educational use. 


\section{FEATURE}

public and private colleges and universities, responded to the survey.

\section{DEFINING OUTREACH}

Libraries support outreach for similar reasons-to reach out to their users, to encourage use of the library and its resources, and to promote a positive image on campus and often in the community-but the activities that libraries use to fulfill these purposes run the gamut. Further complications stem from the interpretation of the term "outreach." Which activities actually constitute outreach? For some libraries, liaison work falls under the banner of outreach, while for other libraries, liaison activities such as collection development and library instruction represent distinctive functions established in libraries. These functions may share similar goals with outreach but do not carry the outreach label. A review of the literature, with the aim of categorizing activities, identifies two categories of outreach and establishes working definitions for this study: services and the promotion of services. Services include (1) any assistance with research or information, (2) the resources available at a library, and (3) library facilities. Promotion of services involves marketing or the use of public relations techniques to promote these services, resources, and facilities.

The literature shows that traditional services, such as liaison work in the form of collection development and library instruction or information literacy programs, still provide a successful way for libraries to reach out to their users. "Embedded librarians" or "satellite librarians" that leave the physical library facility and assist faculty and students in academic departments or student areas represents an emerging trend over the past few years. Other common services include distance education for students and orientations for both faculty and students. Outreach to the community, public libraries, and local schools allows academic libraries to develop partnerships and collaborative programs. ${ }^{2}$

The avenues employed for the promotion of services through marketing and public relations often take the form of communications: websites, e-mails, newsletters, both print and online, blogs, and other Web 2.0 tools assist libraries in promoting their services. Branding and free giveaways also prove popular. Considered a service offered by libraries, orientations play a dual role by serving as a venue for libraries to market services, resources, and facilities to their users. Overwhelming, however, campus and library events, as well as displays and exhibits represent the most common types of outreach activities, and although the literature does not confirm this, possibly the most effective in promoting libraries. ${ }^{3}$

Nomenclature influenced the authors' decision to focus on promotion of services in this study rather than the services themselves. The literature reveals that the terms "outreach," "marketing," and "public relations" are often applied interchangeably. A keyword search using the terms "outreach" and "academic libraries" in the database Library Literature and Information Science is cross-referenced to the controlled vocabulary, "Public Relations of Libraries/College and University Libraries." Further, a review of the literature for the objectives or mission statements of outreach programs often uncover the terms "outreach," "marketing," and "public relations" applied to describe similar philosophies and processes. While libraries ascribe to professional standards and have many commonalities, they express their outreach activities, goals, and philosophies in a range of ways. With backing from the literature regarding the interchangeable use of outreach, marketing, and public relations, however, the authors chose as their operational definition for this study the promotion of services, resources, and facilities through marketing and public relations.

\section{LITERATURE REVIEW}

\section{Management and Support for Outreach}

Scholarly literature on outreach includes a preponderance of "how we did it" accounts of outreach programs and activities implemented by libraries. This review, however, concentrates on the lesser quantity of literature available on two critical aspects of the management and support of outreach: outreach committees and outreach positions. Only a small portion of the literature reviewed mentions budget and staff time devoted to outreach.

Regarding the use of committees, many libraries depend on either formal or ad-hoc committees, along with support from the entire library staff. At Southeastern Louisiana University's Sims Memorial Library, all library employees participate in outreach, but the library also has an outreach committee made up of faculty and staff, which organizes inhouse events. ${ }^{4}$ Butler University Libraries employs a similar approach, using reference librarians to lead outreach efforts but involving all library employees in National Library Week, which helps foster "team spirit." At Georgia State's Pullen Library, the Communication and Public Relations Committee consists of four library faculty and two staff members, all chosen on a yearly basis; three other staff members serve as permanent members of the committee. Despite the use of a committee, it appears that all library staff at Pullen Library assists in fulfilling the committee's mission. ${ }^{6}$ Maureen Brunsdale of Illinois State University's Milner Library argues in favor of this practice, noting that "promotional events should not be carried out by only a handful of people. The entire public services staff can be involved in any promotional campaign."

Although some libraries have created dedicated outreach positions, these assignments often involve working in collaboration with other library staff members who also do outreach. For example, at Mississippi State University Libraries, an Outreach Coordinating Committee (OCC) oversees outreach and a full-time Outreach Coordinator works to expand the "projects of faculty outreach teams." "Likewise, at LSU's Middleton Library, the outreach services librarian is "continually building an outreach team and/or committee that is truly committed to 
outreach." While outreach librarians often work with other library staff, they may take on tasks and responsibilities that other library staff feel lie outside their expertise or job responsibilities. According to Erin Dorney, Outreach Librarian and Chair of the Library Identity and Outreach Committee at Millersville University: "Although I share duties with my peers, the majority of my job requirements are unique to this new position. I provide leadership in marketing and promotion of library initiatives, programs, activities, resources, and services." The library's justification for Dorney's job described a full-time outreach librarian as "essential."

While the literature suggests that many libraries involve all staff in outreach activities - with or without the leadership of an outreach librarian-some libraries lack both an outreach librarian and collaboration among all staff. With only three full-time librarians, no one person or department carries the responsibility of outreach at Our Lady of the Lake College Library in Louisiana. The absence of a designated coordinator or a marketing plan has hindered the library's attempts at outreach. According to librarian Kevin Baggett: "Our outreach efforts, while seemingly successful in some ways, are sporadic and could have been better organized and effective if centralized into one person or group of people." The library will soon create a marketing plan and assign outreach duties to one librarian or form an outreach committee. ${ }^{11}$

Very little research exists as to whether academic libraries choose to fill outreach positions with librarians or other types of professionals. Boff, Singer, and Stearns examine job announcements for outreach positions in academic libraries posted in College \& Research Libraries News (CERL News) from 1970 through 2004. They identified 115 job announcements and grouped these under three categories: distance education outreach, multicultural outreach, and specialized outreach. Job titles in the specialized outreach category match most closely the type of outreach examined in this study, that is, marketing and public relations activities associated with promoting library services and resources. Boff, Singer, and Stearns found marketing and promotion often listed as duties for these specialized positions, with an MLS degree less likely to be a requirement than for positions in distance education and multicultural outreach. This suggests that librarians may not always be chosen to fill these positions, but how often this may occur is not clear. Boff, Singer, and Stearns cited only twenty jobs for specialized outreach, but noted an increase in all types of outreach jobs, especially within the most recent years of their study. ${ }^{12}$

\section{METHOD}

Data collection for the survey occurred in two phases. In the first phase of the study, the authors created an online survey consisting of multiple choice and yes/no questions related to outreach. In keeping with the operational definition developed for this study, the survey used the phrase "outreach/ public relations." The authors selected a representative sample of colleges and universities classified as associate's, baccalaureate, master's, and doctorate-research as defined by the Carnegie Classification of Institutions of Higher Learning. Institutions from all geographic regions of the United States were included in the study. After obtaining approval for the study through the local Institutional Review Board, information letters and a link to the online survey were sent to twenty-five library deans serving at colleges and universities in the four Carnegie Classifications mentioned above.

Sixteen deans (64 percent) completed and returned the pilot survey providing valuable insights for phase 2 of data collection. It was determined that a broader data set could be gathered by distributing the survey to a wider community of academic librarians, including those with first-hand involvement in outreach. To retain confidentiality, library institution names were used only in the data gathering phase to control for duplicate responses collected from the same institution. The addition of open-ended comments allowed respondents to provide more explicit information about their unique outreach programs and activities.

Phase 2 of data collection occurred several months later with the distribution of the revised survey to the professional library listservs, LIBREF-L and academicpr@ala.org. Two data collection periods were orchestrated during a time-span of one month. ${ }^{13}$ During the first period, the survey remained open for ten days and garnered 100 responses. A follow-up invitation a week later resulted in 96 responses and created a total sample size of 196. Fifty-seven surveys from the test population of 196 were eliminated due to: partial responses that did not provide enough data to render the overall survey useful, public library responses (the target population was academic libraries), duplicate submissions from the same institution, and respondents with variant definitions of outreach to the one employed in this study.

\section{RESULTS AND ANALYSIS}

The following discussion reports on results of the online survey. Participants in the survey answered questions regarding outreach positions, outreach committees, funding and time allocated to outreach, outreach mission statements, and activities or tasks defined as outreach.

\section{Outreach Positions}

Of the 139 survey responses, 43.9 percent $(n=61)$ libraries utilize an outreach position. In some cases, the survey's openended comments provide additional information about these positions. Two respondents described new positions, one of which appears to be a full-time assignment in outreach. Conversely, two respondents reported the loss and the possible loss of their respective outreach positions. However, the majority of comments indicate that, of the 61 libraries with an outreach position, many represent half-time appointments. For example, two libraries support an outreach position along 


\section{FEATURE}

with a development or external relations officer; in one of these cases, the person in the outreach position also retains traditional library duties, perhaps splitting his or her assignments. Three additional respondents also discussed the use of half-time positions, with two dividing time between outreach and library work.

A follow-up survey question addresses split appointments and time commitment. Of the 61 libraries with a dedicated outreach position, 37 provided information about the percentage of time these positions devote to outreach. Most employees in this study assigned to an outreach position spend 25-50 percent of their time on outreach (figure 1). This raises questions about the importance placed on outreach by library administrators. However, as the literature review suggests, actual staff time spent on outreach may be higher if one factors in other library staff members who are also involved with outreach. Whether or not enough work exists to justify a fulltime outreach position is another question raised by the data, although one comment describes an individual who spends only 25 percent of his or her time on outreach as "swamped most of the time."

Although knowledge of marketing and public relations techniques may be desirable for some outreach functions, 62.3 percent of the libraries with an outreach position chose to employ a professional librarian for this role. Several factors may account for this high percentage. Professional librarians may have developed marketing and public relations skills through on-the-job training; libraries may split the duties of outreach between a professional librarian, who oversees communications, events, and exhibits, and a separate public relations department responsible for more specialized marketing, such as branding and fundraising; or, librarians in outreach positions may have previous public relations and marketing experience.

\section{Committees}

Of the 139 libraries in this study, 19.4 percent $(n=27)$ make use of an outreach committee. The size of these committees ranges from 3 to 13 members, with an average size of approximately 6 members and a mode of 5 . The time that committees spend on outreach per week averages 7 hours, although this may be skewed by 1 library that devotes 25 hours per week to outreach. Most fall within the 5 to 10 hour range. Libraries that reported having a dedicated outreach position were more likely to have an outreach committee than libraries without an outreach position. Of the 61 respondents who indicated that their library supports an outreach position, just under 25 percent $(n=15)$ reported that their respective libraries also utilize an outreach committee. Of the 78 participants without a dedicated outreach position, 15.4 percent $(n=12)$ reported using a committee for outreach.

The relatively small number of libraries with an outreach committee may be explained by the fact that, in many libraries, all library staff members are encouraged to participate in outreach, thus lessening the need for a committee.

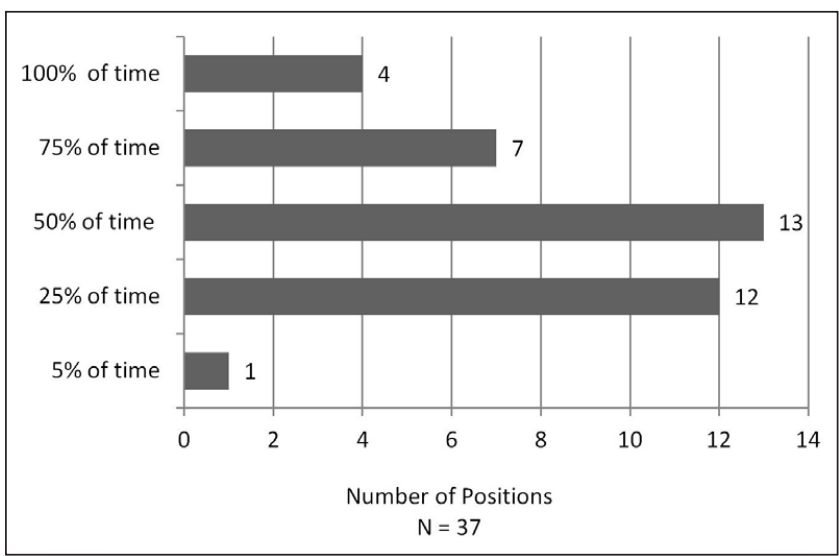

Figure 1. Percentage of Time Dedicated to Outreach

Comments provided by the respondents tend to support this view: "others help on 'as needed' basis"; the outreach librarian "collaborates with groups and departments as needed"; the librarian "coordinates library personnel, all are expected to do outreach"; "people help on various projects"; and "no formal committee but smaller committees that she is usually part of." As noted earlier, the scholarly literature reports similar practices. The survey did not include a question about using general library staff for outreach; this would be a fruitful question for future research. That said, the question remains: Have libraries determined that general staff participation in outreach can accomplish the goals they have set for outreach? Do libraries actually embrace this approach or do they simply fall back on it in the face of lack of administrative support? It could be argued that the scarcity of library literature on specific aspects of outreach-budget, mission statements, and staff time devoted to this function-point to the latter scenario.

Finally, does the size of institution play a role in the use of positions and committees? According to this survey, institutions with larger FTEs prove more likely to maintain an outreach position. No clear trends emerge regarding committees. However, the figures parallel dedicated positions in that the number of committees increases with FTE, with the exception of the four reporting institutions with FTEs of 20,001 to 35,000 (figure 2).

\section{Mission Statements}

While the content of mission statements may reveal more about how libraries define outreach than how they manage and support it, the absence of mission statements, or clearly defined goals and objectives, may also indicate a lack of support for outreach. Less than a quarter $(21.6$ percent; $\mathrm{n}=30$ ) of libraries in the survey indicated the use of a mission statement or a plan for outreach.

Despite this relatively small number, the survey's comments provide valuable insight into the outreach philosophy of these libraries. Nineteen survey participants shared their mission statements, which ranged from one sentence to 


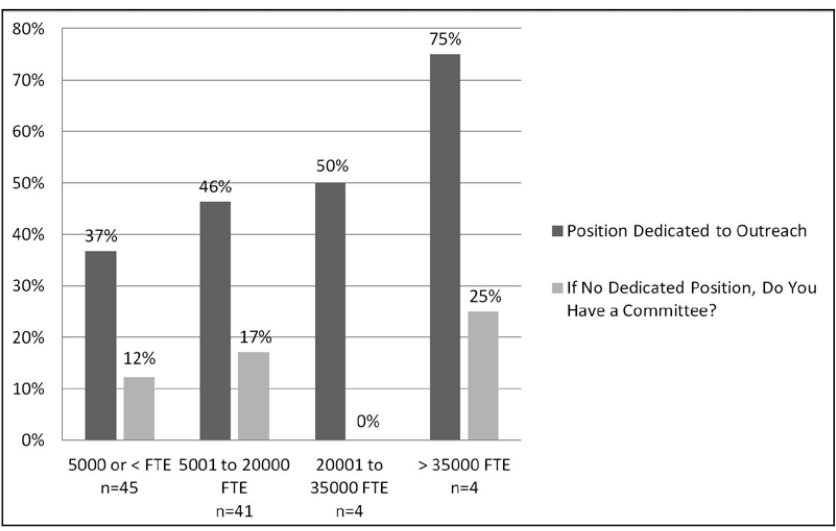

Figure 2. Positions and Committees by Student FTE

several paragraphs in length. All the statements contained similar terminology. Most mentioned one of two major objectives for their outreach programs: (1) to promote library services, resources, collections, facilities, and initiatives, or (2) to raise or increase user awareness of the same. The mission statements often took the form of overarching philosophies for outreach. For example, one library aims to "provide an inclusive window on the changing human experience and sustain social memory through exhibits, art shows, and events." The most commonly used phrases were, "to increase visibility" or "enhance the perception" of the library and its resources. The words "communication" and "cooperation," as well as "campus/community," appear in various statements. Only a few libraries mention specific activities in their statements. For example, two libraries mention "partnering" with the campus community. Two other respondents refer to campus events and exhibits in their mission statements. Finally, some respondents discuss their libraries' overall outreach plans. Examples range from a three-page communications plan to a seventeen-page marketing plan.

\section{Budgets}

A total of 23.2 percent $(n=33)$ respondents indicated that their libraries maintain a budget for outreach. Fourteen of these respondents provided actual figures, revealing budget amounts ranging from $\$ 700$ to $\$ 30,000$. While smaller schools tended to dedicate fewer funds to outreach, the assumption that large institutions maintain large budgets was not borne out by the survey data. In fact, a comparison of budgets with student FTE showed little correlation between enrollment figures and outreach budgets (figure 3). Regardless of enrollment, most budgets in this survey fell below $\$ 5,000$. Similarly, when comparing budgets among types of institutions-private versus public - the survey results failed to confirm that larger, private institutions (presumably better endowed than many smaller, public institutions) devote more resources toward outreach (figure 4). Rather than permanent budgets, the respondents' comments for this question

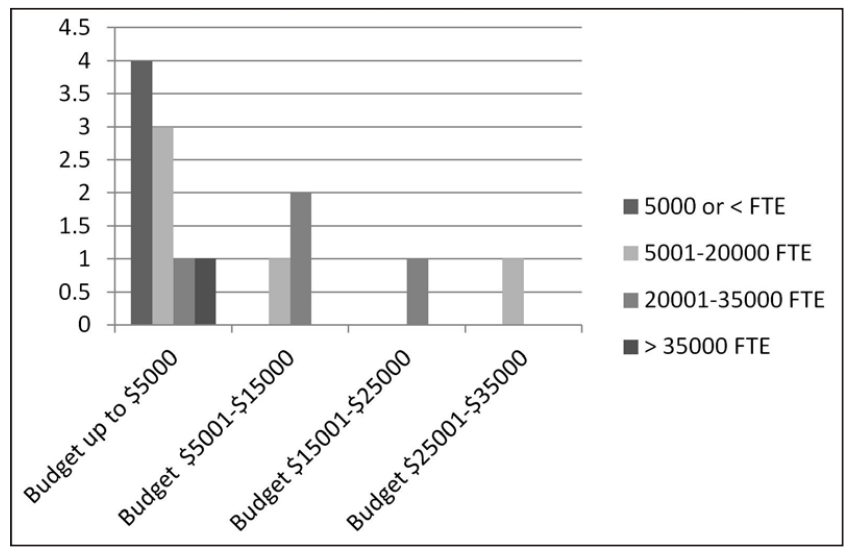

Figure 3. Budgets for Outreach Compared with Student FTE $(\mathrm{N}=14)$

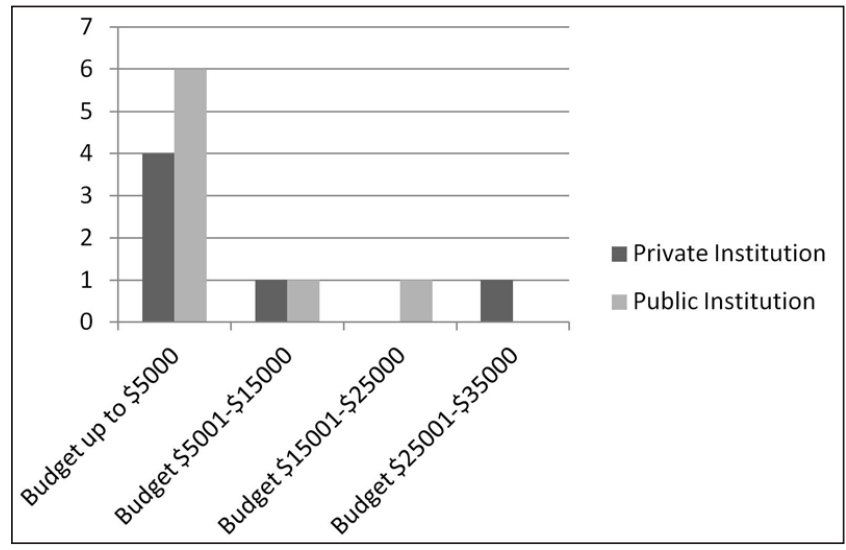

Figure 4. Budgets for Private vs. Public Institutions $(\mathrm{N}=14)$

revealed that funding for outreach may often be provided on a "case-by-case" basis. This model, if widespread, could explain the relatively small number of libraries in the survey that reported dedicated budgets for outreach (table 1).

\section{Activities}

To gather information about the communication venues and library-sponsored events and exhibits used by libraries, the survey asked respondents to select from a menu of outreach activities. Similar to the literature, staging special events proved more prevalent than outreach conducted via communication venues such as blogs, other Web 2.0 technologies, and print and online newsletters (figure 5). A comparison of outreach efforts by student FTE shows that special events, campus and in-house, also are used most often regardless of FTE (figure 6). An open-ended "other" category allowed respondents to list unique outreach activities at their institutions. Among the "other" activities reported, "exhibits" and "art shows/receptions" were mentioned most often. Several respondents' libraries also communicate via campus 


\section{FEATURE}

Table 1. Budget Comments

Director provides money on case-by-case basis

Under the control of the university librarian

No set budget, but per event cost based upon director's discretion

Expenditures covered on ad hoc basis, but director is supportive and buys materials as necessary

Depends on what the library director wants to spend money on

Case by case basis, with some events built into the budget

Money is allocated per project

Requests are considered on a case-by-case basis

Request funds for expenditures individually

Varies by demand

Decisions made one project at a time

Can request money for activities from the general budget

Worked out of regular budget

Based on needs for the year and greatest impact for small budget

We have used money from the general operating budget

Rely on grants

College funds and grants available

newsletters, press releases, radio, and through other forms of marketing and public relations.

\section{Future Plans}

As competition from other information outlets increases, will libraries begin to channel more resources toward outreach? Comments from the 17 respondents whose libraries plan to restructure their outreach programs suggest that this is the case, with plans ranging from the creation of new positions and committees to redistributing the work among library staff (table 2).

\section{A NOTE ON THE DEANS' SURVEY}

As mentioned in "Method," 16 library deans participated in an early pilot survey that consisted of core questions used in the final outreach survey. While the deans' survey did not gather the larger data set achieved by the final outreach survey, it provided insight into the administrative perspective, and foreshadowed some of the results of the larger survey that have been analyzed in this paper. Several foreshadowing elements included the uses of the terms "as needed" and ad hoc.

The deans reported far fewer dedicated outreach positions, but 100 percent of the dedicated positions were filled with professional librarians. As in the final survey, dedicated outreach librarians spent between 25 and 50 percent of their time on outreach duties, again indicating a split-duty assignment. The deans made greater use of committees to carry out the tasks of outreach. In terms of budget and mission, the deans' survey and the final survey align closely (figure 7).

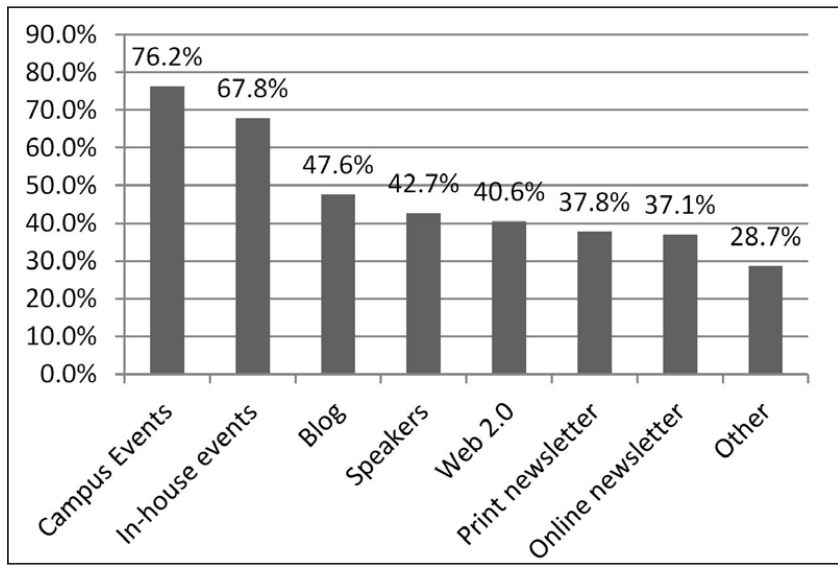

Figure 5. Percent Using Outreach Activity $(\mathrm{N}=134)$

Nineteen percent of the library deans planned to restructure their outreach programs. Comments included a desire "to have more events focusing on students," a need for a "newly created position much more involved with developing programs and establishing relationships," and a plan "to create a position to bring in speakers, events, brown bags, etc."

The deans' survey most closely mirrored the final survey in the results for the question: in which outreach activities does your library participate (figure 8). The consistency between the two surveys regarding activities could indicate that librarians, including administrators, agree at this point in time on which outreach activities are valued and effective.

\section{DISCUSSION AND CONCLUSION}

Exploratory in nature, this research study aimed to investigate how various types of academic libraries support and manage outreach. A list of the results revealed follows:

If library administrations' support for outreach can be gauged by outreach mission statements or measured in terms of dedicated staff positions (and time allocated to them), extent and type of staff involvement, or size of outreach budgets, then this survey finds ample reason to question the adequacy of the support provided for outreach in today's academic libraries. While many libraries participate in different types of outreach, they often do so in informal and ad hoc ways without the benefit of systematic and well thought out outreach programs. What explains this lack of support? Perhaps, given the nature of extemporaneous and discretionary funding for outreach in academic libraries, it is difficult to evaluate its overall effectiveness. Some studies point to the effectiveness of specific outreach services within the library, but few studies assess the results of academic library outreach as a whole. ${ }^{14}$ More complete studies on the effectiveness of outreach may prompt libraries to give this issue more serious thought.

This survey not only provides information about the support and management of outreach in libraries, but it also 


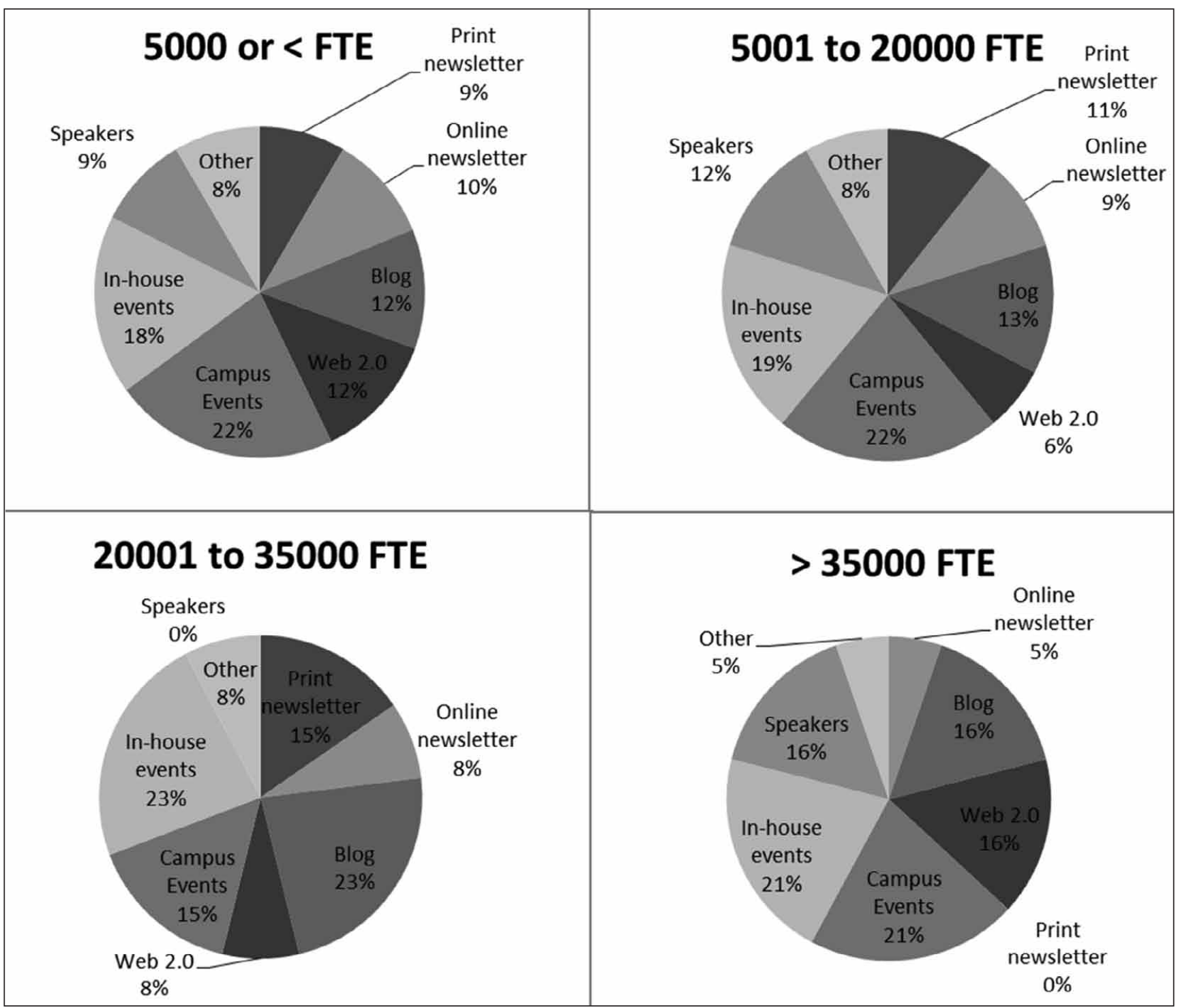

Figure 6. Outreach efforts by size of institution $(\mathrm{N}=94)$

raises questions that could be pursued in future research. The use of half-time appointments for outreach would be an interesting area for additional study. How does the support provided for outreach differ in libraries with full-time appointments as compared to libraries with half-time appointments? Boff, Singer, and Stearns report an increase in outreach positions during the last years of their study, so one might reasonably expect that libraries' support for outreach may grow. ${ }^{15}$ Halftime appointments may be the current norm, with more fulltime appointments in the foreseeable future.

Tight budgets and the need to justify expenditures to library and university administrators will doubtless necessitate a closer look at the efficacy of library outreach programs. Respondents' comments about committees indicated that many libraries perform the tasks of outreach informally or on an ad hoc basis, with little or no guidance from their institutions.
Table 2. Future Plans Comments

I'm in a newly created position to do just this

We hope to have a position dedicated to the graphic arts part of public relations and outreach

New position

Position split between outreach/public services will become a librarian split between outreach/academic liaison for a division

There's an interest in making it a full-time position

Form a committee and create policies and a budget

Create a committee and also adopt a budget

Will create a comprehensive publicity/marketing plan

Outreach will be decentralized and distributed to multiple librarians 


\section{FEATURE}

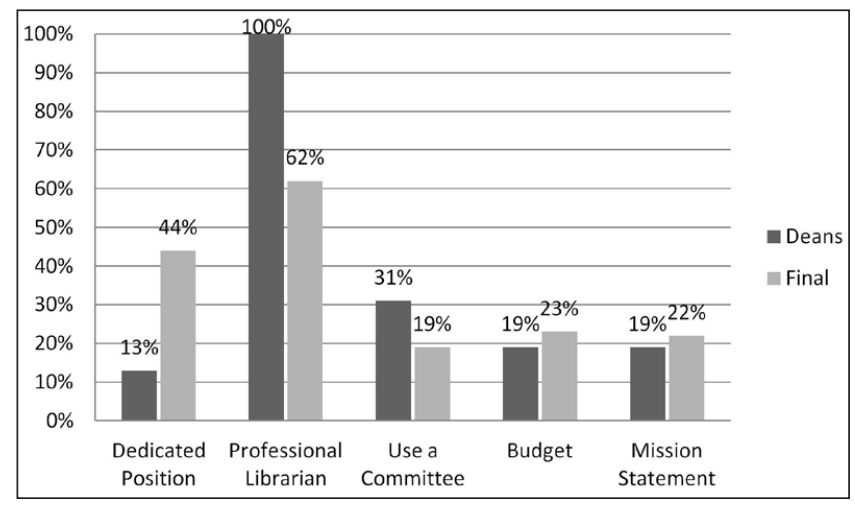

Figure 7. Comparison of the Deans' and Final Surveys

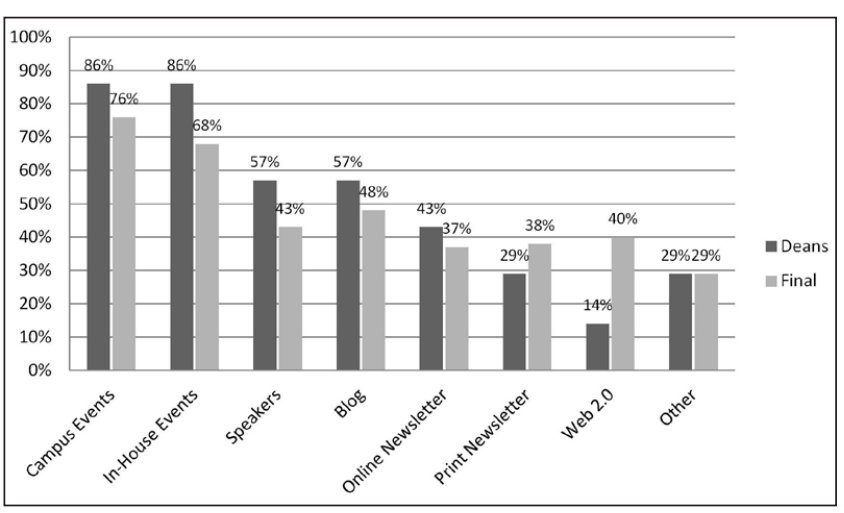

Figure 8. Comparison of Outreach Activities

This informal approach to outreach was summed up in the comment of one respondent: "outreach happens." Is this an efficient way to manage outreach? What type of staffing gets more bang for the buck? A full-time outreach position? A half-time position with a committee? Participation of general library staff? In addition, a more in-depth analysis of the desired skill set of librarians working in marketing and public relations positions is needed. Will librarians be expected to learn these skills on the job, or should library schools offer courses in marketing and outreach?

If libraries plan to compete with the explosion of alternate information outlets in the twenty-first century, outreach may need to be supported by more formalized structures, including thoughtfully articulated mission statements and dedicated budget lines. With less than half of survey respondents reporting having either, it appears that outreach is still an evolving practice.

From grabbing sources off the Internet to studying in a bookstore coffee shop, users have many choices in addition to the library. The library literature and this survey point to the growing use of outreach by libraries as a means to inform users about why they should think of the library when they are seeking information. Regardless of the terminology used-outreach, marketing, or public relations-the need of libraries to reach out to users necessitates additional research in this vital area.

\section{ACKNOWLEDGEMENTS}

The authors extend their gratitude to Dr. Juliet Rumble, Instruction/Reference Librarian at Auburn University, Dr. Tom Buchanan, Associate Professor of Sociology at The University of Tennessee at Chattanooga, C. Daniel Chase, Independent Consultant, and Dr. James A. Ward, Professor of History at The University of Tennessee at Chattanooga for their help with social science survey methods, statistical compilation, and editorial suggestions.

\section{References}

1. Elizabeth Kennedy Hallmark, Laura Schwartz, and Loriene Roy, "The Basics of a Marketing and Outreach Plan for the UT Fine Arts Library," Texas Library Journal 83, no. 1 (Spring 2007): 40.

2. Wendi Arant, "A New Twist to the Electronic Distribution List: A Library Outreach Tool," Internet Reference Services Quarterly 4, no. 2 (1999): 51-55; Kevin Baggett, "Library Outreach at: Our Lady of the Lake College," Louisiana Libraries 71, no. 4 (Spring 2008): 41-44; Maya Riley Banks and Vitalija Svencionyte, "Freshmen Outreach Programs at Southern University," Louisiana Libraries 71, no. 4 (Spring 2008): 32-36; Jennifer L. Corbin, "Resumption and Expansion of Outreach Activities at Tulane University," Louisiana Libraries 71, no. 4 (Spring 2008): 59-61; Gail Peyton, "The Mississippi State University Libraries Outreach Program: Reaching Out," Mississippi Libraries 64, no. 4 (Winter 2000): 104-7; Denise Landry-Hyde, "Outreach at a Public, Academic, Regional LibraryTexas A\&M University-Corpus Christi," Reference Librarian 23, no. 67/68, (1999): 289-98; Phyllis Rudin, "No Fixed Address: The Evolution of Outreach Library Services on University Campuses," Reference Librarian 49, no. 1 (2008): 55-75; Kate Saylor et al., "A Transformational Outreach Program for an Academic Health Sciences Library: Looking Beyond Research Institutions," College E Research Libraries News 72, no. 2 (Feb. 2011): 86-89; Jane E. Schillie et al., "Outreach Through the College Librarian Program at Virginia Tech," Reference Librarian 34, no. 71 (2000): 71-78; Molly Strothmann and Karen Antell, "The Live-In Librarian: Developing Library Outreach to University Residence Halls," Reference \& User Service Quarterly 50, no. 1 (2010): 48-58; Connie Ury and Carolyn Johnson, "Reference Beyond the Walls of the Library: Interacting with Faculty and Students in the 21st Century," Reference Librarian 40, no. 83/84 (2003): 203-18; Clara R. Williams and Tyler O. Walters, "Reference and Instruction Services Go Virtual as a Form of Outreach: Case Studies from Academic Libraries," Information Outlook 7, no. 8 (Aug. 2003): 20-27.

3. Baggett, "Library Outreach at: Our Lady of the Lake College"; Banks and Svencionyte, "Freshmen Outreach Programs at Southern University"; Stephanie Braunstein, "Partner with Outreach as if your Library's Life Depends on It . . . It Quite Possibly Does," Louisiana Libraries 70, no. 4 (Spring 2008): 37-40; Maureen Brunsdale, "From Mild to Wild: Strategies for Promoting Academic Libraries to Undergraduates," Reference \& User Services Quarterly 39, no. 4 (Summer 2000): 331-335; Corbin, "Resumption and Expansion of Outreach Activities at Tulane University"; Erin Dorney, "Academic Outreach Librarianship: A Focus on Publicity and Marketing," Footnotes 38, no. 4 (May 2009): 12-13; Rebecca C. Drummond et al., "From the Library Plaza to the Golden Dome: Reaching Constituents by Committee," Public Services Quarterly 1, no. 3 (2002): 21-35; Mitch Fontenot, "A 'Typical' Year in Outreach Services at 


\section{The Management and Support of Outreach in Academic Libraries}

Louisiana State University Middleton Library," Louisiana Libraries 69, no. 3 (Winter 2007): 3-5; Elizabeth Kennedy Hallmark, Laura Schwartz, and Loriene Roy, "Developing a Long-Range and Outreach Plan for Your Academic Library: The Need for a Marketing Outreach Plan," College \& Research Libraries News 68, no. 2 (February 2007): 92-95 ; Peyton, "The Mississippi State University Libraries Outreach Program"; James G. Rhoades Jr. and Arianne Hartsell, "Marketing First Impressions: Academic Libraries Creating Partnerships and Connections at New Student Orientations," Library Philosophy \& Practice (Aug. 2008): 1-11, http://unllib.unl.edu/ LPP/rhoades-hartsell.htm (accessed May 6, 2010); Karen Sobel, "Promoting Library Reference Services to First-Year Undergraduate Students: What Works?" Reference \& User Services Quarterly 48, no. 4 (Summer 2009): 362-71; Beth Stahr, "Library Outreach at Southeastern Louisiana University," Louisiana Libraries 70, no. 4 (Spring 2008): 45-48; Ury and Johnson, "Reference Beyond the Walls of the Library"; Teresa Williams, "Connections with the Campus Community: Promotional Success through Collaboration and Outreach," Indiana Libraries 27, no. 1 (2008): 35-37.

4. Stahr, "Library Outreach at Southeastern Louisiana University."

5. Williams, "Connections with the Campus Community," 35-37.

6. Drummond et al., "From the Library Plaza to the Golden Dome."
7. Brunsdale, "From Mild to Wild," 333.

8. Peyton, "The Mississippi State University Libraries Outreach Program," 105.

9. Fontenot, "A 'Typical' Year in Outreach Services at Louisiana State University Middleton Library," 4-5.

10. Dorney, "Academic Outreach Librarianship," 12-13.

11. Baggett, "Library Outreach at: Our Lady of the Lake College," 41-44.

12. Colleen Boff, Carol Singer, and Beverly Stearns, "Reaching Out to the Underserved: More Than Thirty Years of Outreach Job Ads," The Journal of Academic Librarianship 32, no. 2 (Mar. 2006): 137-47.

13. Don A. Dillman, Jolene D. Smyth, and Leah Melani Christian, Internet, Mail, and Mixed-Mode Surveys: The Tailored Design Method, 3rd ed. (Hoboken, N.J.: Wiley, 2009).

14. Sobel, "Promoting Library Reference Services to First-Year Undergraduate Students"; Nancy J. Marshall, "Public Relations in Academic Libraries: A Descriptive Analysis," Journal of Academic Librarianship 27, no. 2 (Mar. 2001): 116-121; Ellen Dodsworth, "Marketing Academic Libraries: A Necessary Plan," Journal of Academic Librarianship 24, no. 4 (July 1998): 320-22.

15. Boff, Singer, and Stearns, "Reaching Out to the Underserved." 